\title{
Impact of cropping systems on physico-chemical characteristics of surface water during different seasons in Shimla region of Himachal Pradesh
}

\author{
Aakriti Chauhan*1, S. C. Verma ${ }^{2}$, S. K. Bhardwaj ${ }^{1}$, Uday Sharma ${ }^{3}$, Rakesh Kumar Gupta ${ }^{4}$ \\ and Rajnish Sharma \\ ${ }^{1}$ Department of Env. Science, Dr YS Parmar University of Horticulture and Forestry, Nauni, Solan- 173230 (HP), \\ INDIA \\ ${ }^{2}$ Department of Seed Science and Technology, Dr YS Parmar University of Horticulture and Forestry, Nauni, Solan \\ - 173230 (HP), INDIA \\ ${ }^{3}$ Department of Soil Science and Water Shed Management, Dr YS Parmar University of Horticulture and Forestry, \\ Nauni, Solan- 173230 (HP), INDIA \\ ${ }^{4}$ Department of Basic Science, Dr YS Parmar University of Horticulture and Forestry, Nauni, Solan-173230 (HP), \\ INDIA \\ ${ }^{5}$ Department of Molecular Biology and Biotechnology, Dr YS Parmar University of Horticulture and Forestry, \\ Nauni, Solan- 173230 (HP), INDIA \\ *Corresponding author. E-mail: aakriti.chauhan89@gmail.com
}

Received: August 18, 2015; Revised received: January 7, 2016; Accepted: February 9, 2016

\begin{abstract}
The present investigations were carried out in the year 2014 with an objective to find out the impact of different cropping systems on nearby surface water resources in Shimla region of Himachal Pradesh. The aim of the study was to monitor the surface water bodies for pollution caused by nearby cropping systems in the Shimla area. In this study fruit, fruit + vegetable, vegetable and cereal based cropping systems were selected along with control (uncultivated land) and sampling was done during winter, summer and rainy seasons. The estimated water quality parameters revealed very less organic pollution and $\mathrm{pH}$ values were within the BIS prescribed limits of 6.5-8.5. Under vegetable based cropping system EC $\left(500.23 \mu \mathrm{S} \mathrm{cm}^{-1}\right)$, TDS (329.17 mg/l), BOD (1.48 mg/l), COD (31.09 $\mathrm{mg} / \mathrm{l}), \mathrm{Cl}^{-}(25.66 \mathrm{mg} / \mathrm{l}), \mathrm{Ca}(75.59 \mathrm{mg} / \mathrm{l})$ and $\mathrm{Mg}(11.14 \mathrm{mg} / \mathrm{l})$ were in high concentration, whereas $\mathrm{No}_{3}$ - content were high under fruit + vegetable based cropping system. DO were maximum $(8.61 \mathrm{mg} / \mathrm{l})$ under uncultivated land. Calcium and COD were high in some samples, which could be from anthropogenic sources, rest of the parameters were within the desirable limits prescribed by Bureau of Indian Standards (BIS). The experimental data were statistically analysed through Analysis of variance (two way classification of data) indicated positive correlation among most of the physical and chemical parameters. Study reveals that cropping systems as well as seasonal changes has affected the water quality. The study carried out for water quality parameters, revealed the correlation of each parameter with one another under different cropping systems.
\end{abstract}

Keywords: Agriculture, Cropping system, Intensive farming, Seasons, Water quality

\section{INTRODUCTION}

Cropping systems, an important component of a farming system, represents a cropping pattern used on a farm and their interaction with farm resources, other farm enterprises and available technology. The intensive uses of agriculture inputs and continuous cropping often contribute to environmental deterioration, degrading soil and water resources (Warren et al. 2008). Water quality in agricultural systems is associated with the amount of soil lost as runoff into surface water and with the amount of plant nutrients and pesticides that reach surface waters (Nafziger, 2009). Intensive agriculture and growing demands for energy during the last few decades has affected the physical, chemical parameters and biological attributes of the surface water (Jain et al. 2007). A cropping system affects water quality to the extent that it keeps soil in place, releases little pesticide, and takes up nutrients that would otherwise leave fields in drainage or runoff water. Use of agrochemicals in Himachal Pradesh on various horticultural crops has increased the production and contributed a lot to the economy of the state. But indiscriminate uses of agrochemicals are also responsible for polluting our water resources (Thakur et al. 2012). In the Shimla region the major cropping systems being followed are fruit, vegetable, fruit + vegetable and cereal based cropping systems. Intensive agriculture practices like use of agro chemicals along with other agricultural inputs such as capital and labour are likely to cause degradation of the soil and water quality adjoining to selected cropping 
systems. Studies on effect of cropping system on water quality in Shimla have not been done so far; therefore this study was conducted to identify the pollution present in the surface water resources from nearby farmlands. Water quality in Shimla area has been viewed as un-polluted, however in recent years due to land use change for agriculture practices, pollution due to nonpoint sources have become evident.

\section{MATERIAL AND METHODS}

Water samples were collected under different cropping systems viz., Fruit $-\mathrm{T}_{1}$, Fruit + Vegetable- $\mathrm{T}_{2}$, Vegetable $-\mathrm{T}_{3}$, Cereal- $\mathrm{T}_{4}$ and uncultivated land $-\mathrm{T}_{5}$ was taken as Control. Each treatment was replicated thrice. Sampling was done during winter, summer and rainy seasons. Surface water samples were collected in one litre plastic bottle from streams, springs, Bawri and Nalas. Sampling, preservation and transportation of the samples to the laboratory were done as per standard

\begin{tabular}{|c|c|}
\hline Parameter & Method/ Instrument \\
\hline \multicolumn{2}{|c|}{ Physical parameters } \\
\hline $\mathrm{pH}$ & EUTECH instrument pH 510 \\
\hline $\mathrm{EC} / \mathrm{TDS}$ & $\begin{array}{l}\text { Microprocessor based } \\
\text { conductivity meter }\end{array}$ \\
\hline Turbidity & Digital turbidity meter \\
\hline Temperature & Mercury thermometer \\
\hline \multicolumn{2}{|c|}{ Chemical parameters } \\
\hline DO & Winkler's titration method \\
\hline BOD & $\begin{array}{l}\text { BOD-System Oxidirect System } \\
\text { incubation for five days at } 20^{\circ} \mathrm{C}\end{array}$ \\
\hline COD & $\begin{array}{l}\text { Reflux } \mathrm{K}_{2} \mathrm{Cr}_{2} \mathrm{O}_{7} \text { (TR320 Spec- } \\
\text { troquant) }\end{array}$ \\
\hline $\begin{array}{l}\mathrm{Ca}, \mathrm{Mg}, \mathrm{No}_{3}{ }^{-} \\
\text {and } \mathrm{Cl}\end{array}$ & $\begin{array}{l}\text { Colorimetry (Spectroquant } \\
\text { pharo } 300 \text { Merck made) }\end{array}$ \\
\hline
\end{tabular}

methods (APHA, 2005). The water samples were analyzed for physical and chemical parameters. SPSS Statistics 17.0 software was used for statistical analysis.

\section{RESULTS AND DISCUSSION}

It is evident from Table 1 that $\mathrm{pH}$ of the surface water in Shimla area ranged from 6.69 to 8.41. Amongst all cropping systems highest $\mathrm{pH}$ (7.64) was recorded under fruit based cropping system followed by fruit + vegetable (7.53), vegetable (7.47), cereal (7.28) and control (7.09). Use of chemical fertilizers and their runoff into surface water bodies may have resulted high $\mathrm{pH}$ of surface water. Slightly acidic $\mathrm{pH}$ during rainy season may be due to dilution of surface water by rainfall. Fruit and fruit + vegetable based cropping system were statistically at par $(p<0.05)$ with each other. All the cropping systems differed significantly from control (7.09). Mean values of EC of surface water samples fluctuated between $454.6 \mu \mathrm{S} \mathrm{cm}-{ }^{1}$ and $500.23 \mu \mathrm{S} \mathrm{cm}^{-1}$. There were no significant difference in EC of surface water among the fruit, fruit + vegetable and vegetable based cropping systems. However EC recorded under different farming systems were significantly different $(\mathrm{p}>0.05)$ from control. The study indicated that $\mathrm{pH}$ and $\mathrm{EC}$ were slightly higher in fruit and fruit + vegetable based cropping systems which may be due run off agrochemicals in the nearby water bodies. These findings confirm the findings of Lamptey et al. (2013) who reported that $\mathrm{pH}$ (5.1 to 7.2) and EC (200$8300 \mu \mathrm{S} \mathrm{cm}^{-1}$ ) of Keta Lagoon, Ghana in West Africa were influenced by intensive agriculture and agrochemicals runoff from nearby farmlands.

TDS of surface water ranged from $290.08 \mathrm{mg} / 1$ to

Table 1. Influence of intensive agriculture on physico-chemical parameters of surface water in Shimla.

\begin{tabular}{|c|c|c|c|c|c|c|c|}
\hline \multirow{3}{*}{ Seasons } & \multicolumn{7}{|c|}{ Cropping system } \\
\hline & $\mathbf{F}$ & $\mathbf{F}+\mathbf{V}$ & $\mathbf{V}$ & $\mathbf{C}$ & $\mathbf{U L}$ & Mean & $\mathrm{CD}(p=0.05)$ \\
\hline & \multicolumn{7}{|c|}{ pH } \\
\hline Winter & 7.77 & 7.74 & 7.85 & 7.50 & 7.15 & 7.60 & $\mathrm{~S}=0.11$ \\
\hline Summer & 8.41 & 8.16 & 7.85 & 7.34 & 7.11 & 7.77 & $\mathrm{~T}=0.14$ \\
\hline Rainy & 6.74 & 6.69 & 6.73 & 6.99 & 7.02 & 6.83 & $\mathrm{~S} * \mathrm{~T}=0.25$ \\
\hline \multirow[t]{2}{*}{ Mean } & 7.64 & 7.53 & 7.47 & 7.28 & 7.09 & 7.40 & \\
\hline & \multicolumn{7}{|c|}{$\mathrm{EC}\left(\mu \mathrm{S} \mathrm{\textrm {cm } ^ { - 1 } )}\right.$} \\
\hline Winter & 514.34 & 514.18 & 514.36 & 502.40 & 456.90 & 500.43 & $\mathrm{~S}=9.79$ \\
\hline Summer & 518.66 & 519.17 & 530.70 & 505.63 & 465.68 & 507.97 & $\mathrm{~T}=12.64$ \\
\hline Rainy & 457.45 & 456.09 & 455.63 & 452.03 & 441.22 & 452.48 & $\mathrm{~S} * \mathrm{~T}=\mathrm{NS}$ \\
\hline \multirow[t]{2}{*}{ Mean } & 496.82 & 496.48 & 500.23 & 486.69 & 454.6 & 486.96 & \\
\hline & \multicolumn{7}{|c|}{ TDS(mg/l) } \\
\hline Winter & 338.23 & 340.40 & 337.48 & 331.54 & 300.15 & 329.56 & $\mathrm{~S}=6.54$ \\
\hline Summer & 343.32 & 341.47 & 350.43 & 331.73 & 305.99 & 334.59 & $\mathrm{~T}=8.44$ \\
\hline Rainy & 300.89 & 300.51 & 299.60 & 298.25 & 290.08 & 297.86 & $\mathrm{~S} * \mathrm{~T}=14.63$ \\
\hline \multirow[t]{2}{*}{ Mean } & 327.48 & 327.46 & 329.17 & 320.51 & 298.74 & 320.67 & \\
\hline & \multicolumn{7}{|c|}{ Temperature $\left({ }^{\circ} \mathrm{C}\right)$} \\
\hline Winter & 8.33 & 7.50 & 8.16 & 6.83 & 7.50 & 7.66 & \\
\hline Summer & 24.33 & 23.16 & 23.66 & 21.33 & 24.00 & 23.30 & \\
\hline Rainy & 20.16 & 21.33 & 22.66 & 20.50 & 20.83 & 21.10 & \\
\hline Mean & 17.61 & 17.33 & 18.16 & 16.22 & 17.44 & 17.35 & \\
\hline
\end{tabular}

Where: $\mathrm{F}=$ Fruit; $\mathrm{F}+\mathrm{V}=$ Fruit + Vegetable; $\mathrm{V}=$ Vegetable; $\mathrm{C}=$ Cereal and $\mathrm{UL}=$ Uncultivated land 
Table 2. Influence of intensive agriculture on physico-chemical parameters of surface water in Shimla.

\begin{tabular}{|c|c|c|c|c|c|c|c|}
\hline \multirow{3}{*}{ Seasons } & \multicolumn{7}{|c|}{ Cropping system } \\
\hline & $\mathbf{F}$ & $\mathbf{F}+\mathbf{V}$ & $\mathbf{V}$ & $\mathbf{C}$ & $\mathbf{U L}$ & Mean & $\mathrm{CD}(p=0.05)$ \\
\hline & \multicolumn{7}{|c|}{ Turbidity (NTU) } \\
\hline Winter & 0.46 & 0.35 & 0.29 & 0.25 & 0.23 & 0.32 & $\mathrm{~S}=0.45$ \\
\hline Summer & 3.00 & 1.33 & 0.86 & 0.82 & 0.74 & 1.35 & $\mathrm{~T}=0.64$ \\
\hline Rainy & 4.66 & 3.00 & 2.00 & 0.99 & 0.92 & 2.31 & $\mathrm{~S} * \mathrm{~T}=1.1$ \\
\hline \multirow[t]{2}{*}{ Mean } & 2.71 & 1.56 & 1.05 & 0.69 & 0.63 & 1.33 & \\
\hline & \multicolumn{7}{|c|}{ Biochemical Oxygen Demand (mg/l) } \\
\hline Winter & 0.34 & 0.32 & 0.53 & 0.22 & 0.13 & 0.31 & $\mathrm{~S}=0.54$ \\
\hline Summer & 0.78 & 1.00 & 1.29 & 0.33 & 0.28 & 0.74 & $\mathrm{~T}=0.70$ \\
\hline Rainy & 1.66 & 1.99 & 2.63 & 0.37 & 0.27 & 1.38 & $\mathrm{~S} * \mathrm{~T}=\mathrm{NS}$ \\
\hline \multirow[t]{2}{*}{ Mean } & 0.93 & 1.10 & 1.48 & 0.31 & 0.23 & 0.81 & \\
\hline & \multicolumn{7}{|c|}{ Dissolve oxygen (mg/l) } \\
\hline Winter & 8.43 & 8.14 & 7.30 & 8.66 & 8.93 & 8.29 & $\mathrm{~S}=0.27$ \\
\hline Summer & 7.96 & 7.95 & 7.13 & 8.30 & 8.46 & 7.96 & $\mathrm{~T}=0.35$ \\
\hline Rainy & 7.94 & 7.85 & 6.97 & 8.20 & 8.43 & 7.87 & $\mathrm{~S} * \mathrm{~T}=\mathrm{NS}$ \\
\hline \multirow[t]{2}{*}{ Mean } & 8.11 & 7.98 & 7.13 & 8.38 & 8.61 & 8.04 & \\
\hline & \multicolumn{7}{|c|}{ Chemical Oxygen Demand (mg/l) } \\
\hline Winter & 19.73 & 21.59 & 26.70 & 14.45 & 8.25 & 18.14 & $\mathrm{~S}=2.08$ \\
\hline Summer & 19.91 & 21.78 & 27.70 & 15.19 & 9.00 & 18.71 & $\mathrm{~T}=2.69$ \\
\hline Rainy & 25.19 & 26.90 & 38.89 & 22.85 & 16.30 & 26.03 & $\mathrm{~S} * \mathrm{~T}=\mathrm{NS}$ \\
\hline Mean & 21.61 & 23.42 & 31.09 & 17.49 & 11.18 & 20.96 & \\
\hline
\end{tabular}

Where: $F=$ Fruit; $F+V=$ Fruit + Vegetable; $V=$ Vegetable; $C=$ Cereal and $U L=$ Uncultivated land

$350.43 \mathrm{mg} / 1$ in Shimla region under different cropping systems (Table 1). TDS of surface water samples from vegetable based cropping system showed maximum mean value of $329.17 \mathrm{mg} / \mathrm{l}$ followed by fruit $(327.48$ $\mathrm{mg} / \mathrm{l})$, fruit + vegetable $(327.46 \mathrm{mg} / \mathrm{l})$, cereal based cropping system $(320.51 \mathrm{mg} / \mathrm{l})$ and uncultivated land (298.74 mg/l). Fruit, fruit + vegetable, vegetable based cropping system differed significantly $(\mathrm{p}>0.05)$ with cereal and uncultivated land. The high concentration of TDS in water bodies may be due to addition of $\mathrm{Cl}^{-}$, $\mathrm{No}_{3}{ }^{-}, \mathrm{Ca}$ and $\mathrm{Mg}$ from nearby farm lands. Similar findings were reported by Esmaeili and Johal (2005) in Gobindsagar reservoir, India, who reported that dissolved solids are composed mainly of carbonates, bicarbonates, chlorides, nitrates, calcium, magnesium, phosphates, sulphates etc.

Temperature of surface water resources varied between $6.83{ }^{\circ} \mathrm{C}$ to $24.33{ }^{\circ} \mathrm{C}$ (Table 1) in Shimla region under different cropping systems. Season wise highest temperature were recorded during summer $\left(23.30^{\circ} \mathrm{C}\right)$, followed by rainy $\left(21.10{ }^{\circ} \mathrm{C}\right)$ and winter season $\left(7.66^{\circ} \mathrm{C}\right)$. The variation in the water temperature may be due to different timings of collection of water samples, influence of seasons and atmospheric temperature. These findings are in the confirmations with the findings of Trivedi et al. (2010) who have reported seasonal variation in physical and chemical propertied of drinking water at Kanpur, India.

Turbidity of surface water under fruit based cropping system revealed maximum mean value (2.71 NTU) (Table 2) in the Shimla area, followed by fruit+ vegetable (1.56 NTU), vegetable (1.05 NTU), cereal based cropping system (0.69 NTU) and uncultivated land (0.63 NTU). The turbidity recorded under fruit based cropping system differed significantly ( $p$ values $>0.05$ ) from rest of the cropping systems and control. Season wise turbidity was maximum during rainy season (2.31 NTU) followed by summers (1.35 NTU) and winter season (0.32 NTU). During the rainy season higher value of turbidity observed due to influx of rain water from nearby farmlands, washes silts, sand and cloudiness area. These findings are in confirmation with the findings of Tripathi et al. (2014) who reported anthropogenic impacts on physico- chemical parameters of river Ganga and found highest turbidity during rainy season at Shringverpur, Allahabad.

BOD of surface water under different cropping systems in Shimla region ranged between $0.13 \mathrm{mg} / 1$ to $2.63 \mathrm{mg} / \mathrm{l}$ (Table 2). Mean values for BOD in surface water under fruit based cropping system $(0.93 \mathrm{mg} / \mathrm{l})$ was statistically at par ( $\mathrm{p}$ values $<0.05)$ with fruit + vegetable $(1.10 \mathrm{mg} / \mathrm{l})$ and vegetable $(1.48 \mathrm{mg} / \mathrm{l})$ based cropping systems and differed significantly from cereal $(0.31 \mathrm{mg} / \mathrm{l})$ based cropping system and control $(0.23 \mathrm{mg} /$ 1). Seasonally BOD was maximum during rainy season $(1.38 \mathrm{mg} / \mathrm{l})$ and minimum during winters (0.31 mg/l).

DO in water samples ranged between $6.97 \mathrm{mg} / 1$ to 8.93 $\mathrm{mg} / \mathrm{l}$ (Table 2). Maximum mean value of DO in surface water was obtained under fruit based cropping system $(8.11 \mathrm{mg} / \mathrm{l})$ followed by fruit + vegetable $(7.98$ $\mathrm{mg} / \mathrm{l})$, vegetable $(7.13 \mathrm{mg} / \mathrm{l})$, cereal $(8.38 \mathrm{mg} / \mathrm{l})$ and uncultivated land $(8.61 \mathrm{mg} / \mathrm{l})$. Seasonally maximum DO was recorded during winter season $(8.29 \mathrm{mg} / \mathrm{l})$ and minimum during rainy season $(7.87 \mathrm{mg} / \mathrm{l})$. DO of surface water under cereal and control were statistically at par $(p<0.05)$ with each other. These findings are in agreement with the findings of Oterler 
Table 3. Influence of intensive agriculture on chemical parameters of surface water in Shimla.

\begin{tabular}{|c|c|c|c|c|c|c|c|}
\hline \multirow{3}{*}{ Seasons } & \multicolumn{7}{|c|}{ Cropping system } \\
\hline & $\mathbf{F}$ & $\mathbf{F}+\mathbf{V}$ & $\mathbf{V}$ & $\mathrm{C}$ & $\mathbf{U L}$ & Mean & $\mathrm{CD}(p=0.05)$ \\
\hline & \multicolumn{7}{|c|}{ Nitrate (mg/l) } \\
\hline Winter & 10.00 & 12.00 & 9.33 & 6.33 & 3.33 & 8.20 & $\mathrm{~S}=0.64$ \\
\hline Summer & 12.00 & 13.66 & 14.66 & 7.66 & 4.33 & 10.46 & $\mathrm{~T}=0.82$ \\
\hline Rainy & 7.33 & 7.66 & 8.33 & 6.66 & 3.33 & 6.66 & $\mathrm{~S} * \mathrm{~T}=1.43$ \\
\hline \multirow[t]{2}{*}{ Mean } & 9.77 & 11.11 & 10.77 & 6.88 & 3.66 & 8.44 & \\
\hline & \multicolumn{7}{|c|}{ Chloride (mg/l) } \\
\hline Winter & 16.00 & 24.00 & 32.50 & 14.51 & 13.60 & 20.13 & $\mathrm{~S}=2.08$ \\
\hline Summer & 27.50 & 32.00 & 34.50 & 18.66 & 14.50 & 25.43 & $\mathrm{~T}=2.79$ \\
\hline Rainy & 7.46 & 7.70 & 10.00 & 5.93 & 3.36 & 6.89 & $\mathrm{~S} * \mathrm{~T}=4.66$ \\
\hline \multirow[t]{2}{*}{ Mean } & 16.98 & 21.23 & 25.66 & 13.03 & 10.51 & 17.48 & \\
\hline & \multicolumn{7}{|c|}{ Calcium (mg/l) } \\
\hline Winter & 74.66 & 69.66 & 95.33 & 57.00 & 14.00 & 62.13 & $\mathrm{~S}=8.02$ \\
\hline Summer & 84.66 & 84.93 & 99.11 & 67.66 & 38.33 & 74.94 & $\mathrm{~T}=10.35$ \\
\hline Rainy & 12.66 & 19.33 & 32.33 & 13.00 & 5.00 & 16.46 & $\mathrm{~S} * \mathrm{~T}=17.92$ \\
\hline \multirow[t]{2}{*}{ Mean } & 57.33 & 57.97 & 75.59 & 45.88 & 19.11 & 51.18 & \\
\hline & \multicolumn{7}{|c|}{ Magnesium (mg/l) } \\
\hline Winter & 10.97 & 10.70 & 11.56 & 4.66 & 4.43 & 8.46 & $\mathrm{~S}=0.95$ \\
\hline Summer & 12.56 & 12.56 & 16.43 & 11.36 & 8.96 & 12.38 & $\mathrm{~T}=1.22$ \\
\hline Rainy & 5.96 & 4.46 & 5.43 & 3.26 & 2.13 & 4.25 & $\mathrm{~S} * \mathrm{~T}=2.12$ \\
\hline Mean & 9.83 & 9.24 & 11.14 & 6.43 & 5.17 & 8.36 & \\
\hline
\end{tabular}

Where: $\mathrm{F}=$ Fruit; $\mathrm{F}+\mathrm{V}=$ Fruit + Vegetable; $\mathrm{V}=$ Vegetable; $\mathrm{C}=$ Cereal and $\mathrm{UL}=$ Uncultivated land

et al. (2014), who reported that BOD was lowest and DO were highest during winter season in Tundzha river in Turkey and these parameters were influenced by surrounding farms where cultivation of fruits, vegetables and rice were followed.

COD of surface water under different cropping systems ranged between $8.25 \mathrm{mg} / \mathrm{l}$ to $38.89 \mathrm{mg} / \mathrm{l}$ (Table 2). Maximum mean value for COD were detected in surface water under vegetable based cropping system $(31.09 \mathrm{mg} / \mathrm{l})$ followed by fruit + vegetable $(23.42 \mathrm{mg} / \mathrm{l})$, fruit $(21.61 \mathrm{mg} / \mathrm{l})$, cereal $(17.49)$ and uncultivated land $(11.18 \mathrm{mg} / \mathrm{l})$. Seasonally, COD were maximum $(26.03 \mathrm{mg} / \mathrm{l})$ during rainy season and minimum $(18.14 \mathrm{mg} / \mathrm{l})$ during winters, which were significantly at par $(\mathrm{p}<0.05)$ with COD recorded during summer season $(18.71 \mathrm{mg} / \mathrm{l})$ in Shimla region.
COD of surface water under vegetable based cropping systems differed significantly $(\mathrm{p}>0.05)$ with rest of the cropping systems along with control i.e. uncultivated land. COD were high during rainy season (26.03 $\mathrm{mg} / \mathrm{l})$ which may be due to surface runoff of organic waste from nearby farms. These findings are in confirmation with the findings of Upkar and Vyas, (1992) who also reported that high value of COD may be due to high degree of organic pollution in Mansarovar reservoir, Bhopal.

Maximum mean value of $\mathrm{NO}_{3}{ }^{-}$in surface water in Shimla area under different cropping systems was observed under fruit + vegetable based cropping system (11.11 mg/l) (Table 3), followed by vegetable $(10.77 \mathrm{mg} / \mathrm{l})$, fruit $(9.77 \mathrm{mg} / \mathrm{l})$, cereal $(6.88 \mathrm{mg} / \mathrm{l})$ and uncultivated land $(3.66 \mathrm{mg} / \mathrm{l})$. Seasonally maximum

Table 4. Pearson correlations between water quality parameters under different cropping systems.

\begin{tabular}{|c|c|c|c|c|c|c|c|c|c|c|c|c|}
\hline Parameter & pH & EC & TDS & Turbidity & $\begin{array}{l}\mathrm{COD} \\
\mathrm{mg} / \mathrm{l}\end{array}$ & $\begin{array}{c}\text { BOD } \\
\mathrm{mg} / \mathrm{l}\end{array}$ & Ca mg/l & $\underset{1}{M g ~ m g / ~}$ & $\begin{array}{l}\mathrm{No3} \\
\mathrm{mg} / \mathrm{l}\end{array}$ & Cl mg/l & $\begin{array}{c}\text { DO } \\
\text { mg/l }\end{array}$ & $\begin{array}{c}\text { Temp } \\
{ }^{\circ} \mathbf{C}\end{array}$ \\
\hline$\overline{\mathrm{pH}}$ & 1 & & & & & & & & & & & \\
\hline $\mathrm{EC}$ & $.827^{* *}$ & 1 & & & & & & & & & & \\
\hline TDS & $.832^{* *}$ & $.997^{* *}$ & 1 & & & & & & & & & \\
\hline Turbidity & -.262 & -.223 & -.213 & 1 & & & & & & & & \\
\hline COD mg/l & -.110 & .010 & .017 & $.352^{*}$ & 1 & & & & & & & \\
\hline BOD mg/l & -.281 & -.111 & -.104 & $.442^{* *}$ & $.564^{* *}$ & 1 & & & & & & \\
\hline $\mathrm{Ca} \mathrm{mg} / \mathrm{l}$ & $.841^{* *}$ & $.907^{* *}$ & $.905^{* *}$ & -.254 & .109 & -.082 & 1 & & & & & \\
\hline $\mathrm{Mg}$ mg/l & $.740^{* *}$ & $.828^{* *}$ & $.818^{* *}$ & -.137 & .100 & -.006 & $.869^{* *}$ & 1 & & & & \\
\hline No3 mg/l & $.679^{* *}$ & $.748^{* *}$ & $.759^{* *}$ & .089 & $.457^{* *}$ & .217 & $.775^{* *}$ & $.776^{* *}$ & 1 & & & \\
\hline $\mathrm{Cl} \mathrm{mg/1}$ & $.819^{* *}$ & $.835^{* *}$ & $.827^{* *}$ & -.232 & .076 & -.080 & $.875^{* *}$ & $.875^{* *}$ & $.746^{* *}$ & 1 & & \\
\hline DO mg/l & -.072 & -.200 & -.202 & -.231 & $-.792^{* *}$ & $-.586^{* *}$ & $-.303^{*}$ & $-.337^{*}$ & $-.486^{* *}$ & $-.341^{*}$ & 1 & \\
\hline Temperature ${ }^{\circ} \mathrm{C}$ & -.138 & -.186 & -.185 & $.477^{* *}$ & .249 & $.371^{*}$ & -.113 & .120 & .135 & -.057 & $-.323^{*}$ & 1 \\
\hline
\end{tabular}

**Correlation is significant at the 0.01 level (2-tailed); *Correlation is significant at the 0.05 level (2-tailed). 
$\mathrm{NO}_{3}^{-}(10.46 \mathrm{mg} / \mathrm{l})$ content were observed during summers, which were significantly different $(\mathrm{p}>0.05)$ from rainy season $(6.66 \mathrm{mg} / \mathrm{l})$ as well as winter season $(8.20 \mathrm{mg} / \mathrm{l}) . \quad \mathrm{NO}_{3}{ }^{-}$content of surface water under fruit + vegetable and vegetable based cropping systems was statistically at par with each other and differed significantly from rest of the cropping systems and control. $\mathrm{NO}_{3}^{-}$may arise from the excessive application of fertilizers, leaching and runoff of wastewater or other organic wastes into surface water bodies (WHO 2006).

$\mathrm{Cl}^{-}$content in surface water in Shimla area under different cropping systems ranged between $3.36 \mathrm{mg} / 1$ to $34.50 \mathrm{mg} / \mathrm{l}$. Maximum mean value for $\mathrm{Cl}^{-}$in surface water was under vegetable based cropping system $(25.66 \mathrm{mg} / \mathrm{l})$ followed by fruit + vegetable $(21.23 \mathrm{mg} /$ 1), fruit $(16.98 \mathrm{mg} / \mathrm{l})$, cereal $(13.03 \mathrm{mg} / \mathrm{l})$ and control (10.51 mg/l). Seasonally, $\mathrm{Cl}^{-}$content were maximum $(25.43 \mathrm{mg} / \mathrm{l})$ during summers, which were significantly different $(p$ values $>0.05)$ from rainy season (6.89 $\mathrm{mg} / \mathrm{l})$ as well as winter season $(20.13 \mathrm{mg} / \mathrm{l}) . \mathrm{Cl}^{-}$ content of surface water under vegetable based cropping system differed significantly $(p>0.05)$ from all other cropping systems and control. Presence of $\mathrm{Cl}^{-}$ content in water bodies is the indication of organic waste of animal origin and this contamination may be due to nearby agriculture farms. These findings confirm the findings of Kumar et al. (2006) who studied the Ranjit Sagar Reservoir, Jammu and Kashmir and reported that $\mathrm{Cl}^{-}$content in surface water is regarded as an indication of organic load of animal origin.

Data presented in Table 3 for study of impact of cropping systems on physico-chemical parameters of surface water in Shimla region revealed that calcium in surface water samples ranged from $5 \mathrm{mg} / \mathrm{l}$ to $99.11 \mathrm{mg} /$ 1. Mean values of $\mathrm{Ca}$ in surface water under vegetable (75.59 $\mathrm{mg} / \mathrm{l})$ based cropping systems differed significantly $(\mathrm{p}>0.05)$ from fruit $(57.33 \mathrm{mg} / \mathrm{l})$, fruit + vegetable $(57.97 \mathrm{mg} / \mathrm{l})$, cereal based cropping system (45.88 mg/l) and control (19.11 mg/l) i.e. uncultivated land. Seasonally, summer season revealed maximum Ca content $(74.94 \mathrm{mg} / \mathrm{l})$ which were significantly different from $\mathrm{Ca}$ content observed during winters $(62.13 \mathrm{mg} / \mathrm{l})$ and rainy season $(16.46 \mathrm{mg} / \mathrm{l})$. Mg content was highest $(12.38 \mathrm{mg} / \mathrm{l})$ during summer season and lowest $(4.25 \mathrm{mg} / \mathrm{l})$ during rainy season, which shows that they significantly differed ( $\mathrm{p}$ values $>0.05$ ) from each other. Mean values of $\mathrm{Mg}$ in surface water were high under vegetable based cropping system (11.14 mg/l) (Table 3) which were statistically different from fruit $(9.83 \mathrm{mg} / \mathrm{l})$, fruit + vegetable $(9.24$ $\mathrm{mg} / \mathrm{l})$ cereal $(6.43 \mathrm{mg} / \mathrm{l})$ based cropping system and control $(5.17 \mathrm{mg} / \mathrm{l})$. The presence of $\mathrm{Ca}$ and $\mathrm{Mg}$ in surface water may be due to runoff of chemical fertilizers from surrounding farms. These findings corroborate the findings of Agu et al. (2014) who reported that chemical fertilizers contain volumes of elements ranging from macro nutrient such as nitrate, phosphate and potassium and trace elements such as calcium, magnesium, iron, copper etc.

Correlation matrix: During the present study this is evident from Table 4 that $\mathrm{pH}$ and EC (0.827), EC and TDS (0.997), $\mathrm{pH}$ and TDS (0.832) are strongly correlated to each other and negatively correlated to turbidity. EC, $\mathrm{pH}$, TDS are positively correlated to $\mathrm{Ca}$, $\mathrm{Mg}, \mathrm{Cl}^{-}$and $\mathrm{No}_{3}-$, which means that increase in nutrient content of surface water body has increased $\mathrm{pH}$, $\mathrm{EC}$ and TDS, respectively. $\mathrm{No}_{3^{-}}, \mathrm{Mg}, \mathrm{Ca}$ and $\mathrm{Cl}^{-}$are positively correlated to each other showing their common source of origin. Agriculturally induced water pollution may occur from point sources as well as through diffuse pollution from farm land. $\mathrm{pH}$ shows negative correlation with BOD $(-0.281)$ and COD $(-0.110)$. DO and BOD (-0.586) are negatively correlated to each other which mean increase in demand of DO would decrease the BOD of surface water bodies. Positive loading were observed between $\mathrm{Cl}^{-}$and $\mathrm{Ca}(0.875), \mathrm{No}_{3}-$ and $\mathrm{COD}(0.457)$ as well as BOD and COD (0.564). These findings confirm the findings of Manssour and Al-Mufti, (2010) who reported similar findings in Quttina Lake in the middle region of Syria. Temperature is positively correlated to turbidity, COD, BOD and negatively with TDS, $\mathrm{Cl}^{-}$, $\mathrm{No}_{3}-, \mathrm{Mg}$, and $\mathrm{Ca}$. The pressure of intensive agriculture may impact water quality particularly via nutrient loss from land to water Murphy et al. (2015). The nutrients and agrochemicals applied in the fields may reach adjacent surface water bodies over land flows and subsurface flows during precipitation events or, at a slower rate, reach surface water bodies through groundwater discharge (Johannsen and Armitage, 2010).

\section{Conclusion}

Impact of cropping systems on physico-chemical characteristics of surface water during different seasons in Shimla region of Himachal Pradesh have revealed the significant impact of cropping systems on water quality. The investigated hypothesis showed significant difference in the occurrence of physical and chemical properties of water. Water quality under vegetable based cropping system was reported with higher concentration of nutrients and under control site there were less organic pollution along with low level of pollutants. Intensive farming under different cropping systems impacted the quality of water and among these, the stresses (agricultural, horticultural and wasteland) are impacting largely on water quality. All the water quality parameters were within desirable limits except $\mathrm{Ca}$ according to Bureau of Indian standards (BIS). High content of $\mathrm{Ca}$ in surface water during winter and summer seasons under the fruit and fruit + vegetable cropping systems may be due to anthropogenic sources such as from $\mathrm{Ca}$ containing fertilizers or it could be from geological origin. Careful planning of land use, shifting towards organic agriculture and minimizing the use of agrochemicals is needed to bring significant reductions in nutrient 
exports from agriculture land.

\section{ACKNOWLEDGEMENT}

Authors are thankful to the Dean College of Forestry for providing necessary facilities which were required for conducting this research work.

\section{REFERENCES}

Agu, C.C., Menkiti, M.C., Okolo, B.I. and Nnaji, P.C. (2014). Evaluation of the Level and Impact of Selected Physiochemical Parameters of Fertilizer Effluent on Obinna River, Adani, Enugu State, Nigeria. J. Water Resource Prot. 6: 722-730.

APHA. (2005). Standard methods for the examination of water and wastewater, $19^{\text {th }}$ Edn. Published by American Public Health Association, 1015, fifteen street NW Washington, D.C. 20 R.C. 0015.

Esmaeili, H.R., Johal, M.S. (2005). Study of physicochemical parameters of water of Gobindsagar reservoir, India, In: Proceeding of National Seminar on 'New Trends in Fishery Development in India'(Ed: M.S. Johal) Punjab University, Chandigarh, India. pp. 173-177.

Jain, S.K., Agarwal, P.K., Singh, V.P. (2007). Hydrology and water resources of India. Dordrecht, The Netherlands: Springer. $1258 \mathrm{p}$.

Johannsen, S.S. and Armitage, P. (2010). Agricultural practice and the effects of agricultural land -use on water quality. Fresh Water Forum. 28: 45-59.

Kumar, A., Qureshi, T.A., Parashar, A. and Patiyal, R.S. (2006). Seasonal variation in physicochemical characteristics of Ranjit Sagar Reservoir, Jammu and Kashmir. The Academy of Environmentl Biology. India J. Ecophysiol. Occup. Health. 6 (3-4):159-63.

Lamptey, A.M., Ofori-Danson, P.K., Mickson, S.A., Breuning-Madsen, H. and Abekoe, M.K. (2013). The Influence of Land-Use on Water Quality in a Tropical Coastal Area: Case Study of the Keta Lagoon Complex, Ghana, West Africa. Open J. Mod. Hydrol. 3: 188-195.
Manssour, K. and Al-Mufti, B. (2010). Influence of Industrial, Agricultural and Sewage Water Discharges on Eutrophication of Quttina Lake. Jordan J. Civ. Eng. 4(4): 351-366.

Murphy, P.N.C., Mellander, P.E., Melland, A.R., Buckley, C., Shore, M., Shortle, G., Wall, D.P., Treacy, M., Shine, O., Mechan, S. and Jordan, P. (2015). Variable response to phosphorus mitigation measures across the nutrient transfer continuum in a dairy grassland catchment. Agric. Ecosyst. Environ. 207: 192-202.

Nafziger, E. (ed.) (2009). Cropping Systems. Illinois Agronomy Handbook, 49p. From, http://extension. cropsciences.illinois.edu/handbook/pdfs/chapter05.pdf.

Oterler, B., Kirgiz, T. and Albay, M. (2014). Seasonal Variations of Water Quality Parameters and Algal Flora of Tundzha (Tunca) River (Edirne, Turkey). Open $J$. Ecol. 4: 807-819.

Thakur, M., Verma, S.C., Brahmi, M.K. (2012). Status and impact of agrochemicals in horticulture ecosystem in Himachal Pradesh, Agriculture Today, pp. 52-53.

Tripathi, B., Pandey, R., Raghuvanshi, D., Singh, H., Pandey, V. and Shukla, D.N. (2014). Studies on the physico-chemical parameters and correlation coefficient of the river Ganga at Holy Place Shringverpur, Allahabad. IOSR J. Environ. Sci. Toxico. Food Techno. 8(10):29-36.

Trivedi, P., Bajpai, A. and Thareja, S. (2010). Comparative study of seasonal variation in physico-chemical characteristics in drinking water quality of Kanpur, India with reference to 200 MLD filtration plant and ground water. Nature Sci. 8(4): 11-17.

Upkar N A and Vyas A. (1992). Correlation between copepodes and limnochemistry of Mansarovar reservoir, Bhopal. J. Aquat. Biol. 13: 281-290.

Warren, J., Lawson, C., Belcher, K. (2008). The Agri environment. Cambridge University Press, Cambridge, $224 p$.

WHO. (2006). Guidelines for Drinking Water Quality. First Addendum to Third Edition, 1, WHO, Genva. 